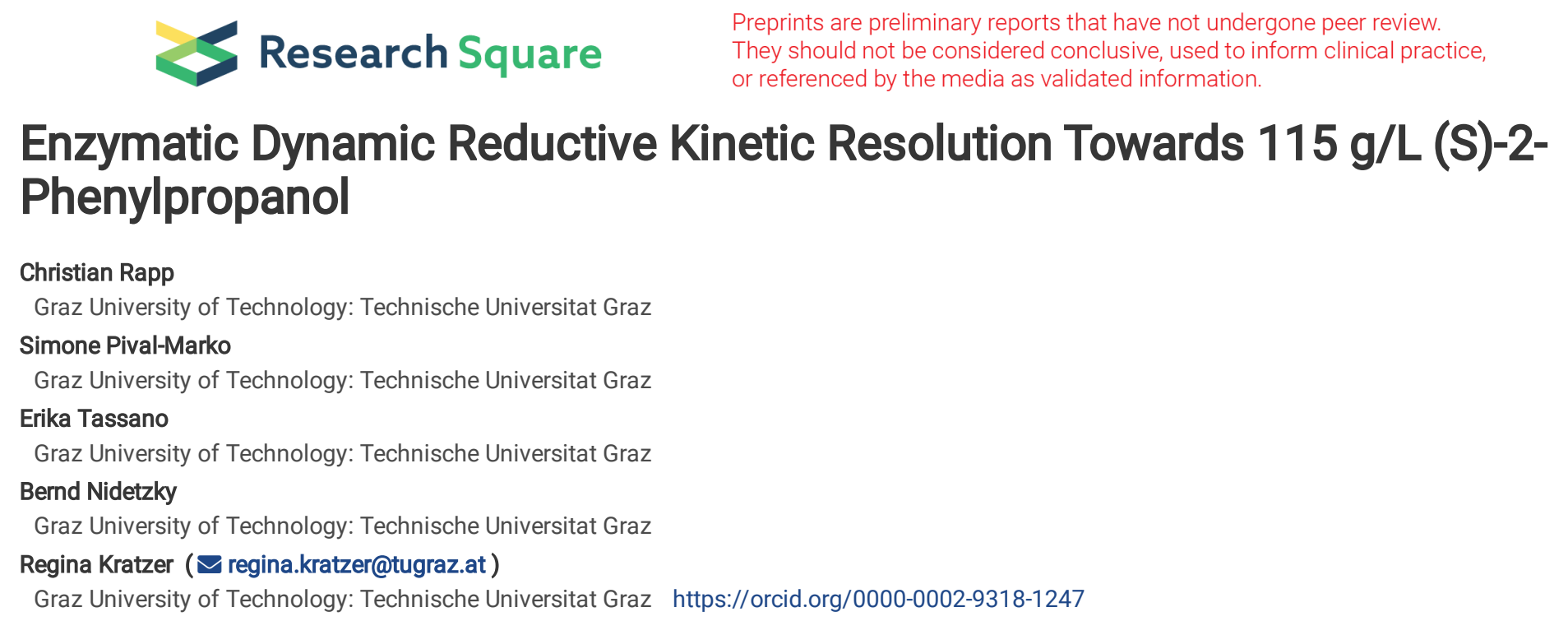

\section{Enzymatic Dynamic Reductive Kinetic Resolution Towards 115 g/L (S)-2- Phenylpropanol}

Research

Keywords: Enantiopure 2-aryl-1-propanol, dynamic reductive kinetic resolution, biocatalyst stability, aldo-keto reductase engineering

Posted Date: February 11th, 2021

DOI: https://doi.org/10.21203/rs.3.rs-183141/v1

License: (c) (i) This work is licensed under a Creative Commons Attribution 4.0 International License. Read Full License 


\section{Abstract}

Background

Published biocatalytic routes towards chiral 2-phenylpropanol by oxidoreductases showed product concentrations of maximally 80 mM. Enzyme deactivation turned out as one major limitation and was attributed to adduct formation of the aldehyde substrate with the catalytic reductase.

Results

A Candida tenuis xylose reductase single-point mutant (CtXR D51A) with very high catalytic efficiency $\left(43 \cdot 10^{3} \mathrm{~s}^{-1} \mathrm{M}^{-1}\right)$ for $(S)$-2-phenylpropanal was identified. The enzyme showed high enantioselectivity for the $(S)$-enantiomer but was deactivated by $0.5 \mathrm{mM}$ substrate within $2 \mathrm{~h}$. A whole-cell biocatalyst based on the engineered reductase and a yeast formate dehydrogenase for NADH-recycling provided substantial stabilization of the reductase. The relatively slow in situ racemization of 2-phenylpropanal and the still limited biocatalyst stability required a subtle adjustment of the substrate-to-catalyst ratio. A value of $3.4 \mathrm{~g}_{\text {substrate }} / \mathrm{g}_{\text {cell-dry-weight }}$ turned out as compromise between product enantiopurity and conversion. A catalyst loading of $40 \mathrm{~g}_{\text {cell-dry-weight }}$ was used to convert $1 \mathrm{M}$ racemic 2-phenylpropanal to (S)-phenylpropanol in $93.1 \%$ e.e.

Conclusion

Mainly hydrolases have been exploited for the production of profenols at industrial scale so far. The herein established bioreduction presents an alternative route towards profenols that is competitive to hydrolase-catalyzed kinetic resolutions.

\section{Highlights}

- A Candida tenuis xylose reductase D51A mutant showed a 270-fold higher enzymatic activity and improved enantioselectivity for (S)-2phenylpropanal compared to the wild-type enzyme.

- Use of a whole-cell catalyst stabilized the enzyme $>1000$-fold under reaction conditions.

- Efficient kinetic resolution of racemic 2-phenylpropanal by a whole-cell catalyst was demonstrated.

- (S)-2-phenylpropanol was produced in $843 \mathrm{mM}$ and $93.1 \%$ e.e.

- The substrate-to-biocatalyst ratio was the main factor determining product enantiopurity and concentration.

\section{Background}

2-Aryl-1-propanols are key core synthons of profen-type non-steroidal anti-inflammatory drugs (NSAIDs) (1). The simplest 2-aryl-1-propanol, 2phenylpropanol (Lilac-Hyacinth odor), is a fragrance ingredient of personal care products itself but is also used as precursor in the synthesis of further fragrances $(2,3)$. Differing biological activities of $R$ - and $S$-profens as well as enantioselectivity in odor perception have drawn attention towards production of optically pure 2-aryl-1-propanols. Over the last decades, a number of biocatalytic routes have been proposed including kinetic resolutions by hydrolases, nitrile-converting enzymes or oxidases, asymmetrization of prochiral precursors by enzymatic decarboxylation and isomerization by styrene oxide isomerase. Kinetic resolutions by means of hydrolases and oxidoreductases are the two most advanced strategies (reviewed in 4). The economic attractiveness of kinetic resolutions, that are restricted to maximally $50 \%$ yield, are increased by in situ racemization of the unused antipode in dynamic kinetic resolution (DKR). DKR strategies exploiting hydrolases and oxidoreductases make use of the relatively fast racemization of 2-aryl-1propanoic acids/esters and 2-aryl-1-propanals (Scheme 1). Hydrolase-catalyzed kinetic resolutions were the first biocatalytic routes towards enantiopure profens and numerous lipases and esterases have been tested for their enantioselectivities towards several profens (5). Product concentrations of $0.5 \mathrm{M}$ and enantiopurities of up to $99 \%$ e.e. were reported and hydrolases have been exploited at industrial scale (6, 7). Hydrolases are still attractive, though with less IP opportunities (4). Oxidoreductases are an interesting alternative, however, less investigated. Previously published biocatalytic routes towards chiral profenols by oxidoreductases show markedly lower product concentrations of maximally $80 \mathrm{mM} 2$-aryl-1-propanols $(4,8,9,10,11,12)$. However, oxidoreductases generally outperform hydrolases in terms of enantioselectivity. Here, we report on an enzymatic dynamic reductive kinetic resolution towards $(S)$-2-phenylpropanol. A single point mutant of the xylose reductase from Candida tenuis (CtXR, superfamily of aldoketo reductases) with high catalytic activity and excellent enantioselectivity for (S)-2-phenylpropanal was used in $E$. coli whole-cell reductions. Reaction optimization with the aim to achieve high enantioselectivity and product concentration at full conversion was accomplished. The established enzymatic dynamic reductive kinetic resolution (DYRKR) is compatible with lipase-based processes in terms of product concentration and optical purity.

\section{Results}

Motivated by a basal activity of wild-type CtXR on rac-2-phenylpropanal $\left(k_{\text {cat }} / K_{\mathrm{m}, \text { rac }} 130 \mathrm{~s}^{-1} \mathrm{M}^{-1}, k_{\text {cat }} 0.05 \mathrm{~s}^{-1}\right)$, we tested a number of substrate binding mutants for activity and enantioselectivity in the reduction of 2-phenylpropanal. The used enzyme is a member of the aldo-keto reductase superfamily (AKRs) and converts xylose to xylitol in the central sugar metabolism of its native host Candida tenuis. CtXR shows, like many other AKRs, broad substrate specificity. Its biocatalytic applicability was, however, limited by moderate catalytic activity and low stability of the wild-type enzyme. Several substrate-binding site mutants with improved specificity for aromatic ketones were used in the synthesis of $(R)$-ethyl mandelates and $(S)$ phenylethanols $(13,14)$. 
The substrate-binding cavity of aldo-keto reductases is mainly formed by residues from three large and flexible loops $(15,16)$. Loop flexibilities provide the structural basis for relaxed substrate specificities but complicate rational engineering (17). A binding mode of the natural substrate $D$-xylose (open chain form) was previously modelled with C-1 of xylose within hydride-transfer distance above the nicotinamide C-4 and the carbonyl oxygen hydrogenbonded to the general acid catalyst Tyr-52. Therein, the aldehyde hydrogen pointed towards the indole ring of Trp- 24 , the $\mathrm{C} 2 \mathrm{hydroxyl}$ interacted with Asn-310 and C3, C4 and C5 hydroxyls with Asp-51 (18). Here, we probed CtXR wild-type and single-point mutants of the main substrate recognition residues Trp-24, Asn-310 and Asp-51 as catalysts for 2-phenylpropanal reduction. The replacement of Trp-24 by smaller phenylalanine and tyrosine increased activities on bulky ketone-substrates $(13,19)$. Asp-51 contributes the most to the relative polarity of the binding site; substitution by alanine led to improved selectivity for the aromatic ketone o-chloroacetophenone (14).

\section{Kinetic constants of 2-phenylpropanal reduction by CtXR variants}

Table 1 summarizes results of a steady-state kinetic analysis of NADH-dependent reduction of racemic and (S)-2-phenylpropanal by $C t X R$ wild-type and mutants.

Racemic substrate. The wild-type enzyme showed a specificity constant $\left(k_{\text {cat }} / K_{\mathrm{m} \text {,rac }}\right)$ of $130 \mathrm{~s}^{-1} \mathrm{M}^{-1}$ reflected by a $K_{\mathrm{m} \text {,rac }}$ value of $350 \mu \mathrm{M}$ and a $k_{\text {cat }}$ value of $0.05 \mathrm{~s}^{-1}$. The mutants W24F and W24Y displayed only 8 to $10 \%$ of the wild-type activity. While the N310A mutant had a specificity constant similar to the wild-type, the N310D mutant showed no activity. CtXR D51A stood out with a $k_{\text {cat }} / K_{\mathrm{m}, \text { rac }}$ of $28 \cdot 10^{3} \mathrm{~s}^{-1} \mathrm{M}^{-1}$ composed of a $K_{\mathrm{m}, \text { rac }}$ value of $170 \mu \mathrm{M}$ and a $k_{\text {cat }}$ value of $4.8 \mathrm{~s}^{-1}$. Replacement of the charged aspartic acid by alanine led to 215 -fold higher catalytic efficiency compared to the wildtype. Likewise, introduction of an additional aspartic acid in the substrate binding pocket (N310D mutant) abolished the activity with 2-phenylpropanal. Note that used CtXR mutants showed 35 to 100 -fold reduced catalytic activity towards the natural substrate xylose (19). Enlargement of the substrate binding pocket by replacement of the bulky Trp24 decreased the enzyme's activity towards 2-phenylpropanal.

(S)-2-phenylpropanal. Kinetic parameters obtained with the racemic substrate and the (S)-2-phenylpropanal were compared and the ratio of the specificity constants formed $\left(k_{\text {cat }} / K_{\mathrm{m}, \mathrm{S}}\right) /\left(k_{\mathrm{cat}} / K_{\mathrm{m} \text { rac }}\right)$ (Table 1$)$. For the extreme case of sole activity with the $S$-enantiomer, a ratio of $\sim 2$, for equal acceptance of $S$ and $R$-enantiomer a ratio of 1 and for preference of the $R$-enantiomer ratios $<1$ were expected. The wild-type showed a ratio of 1.23 and preference for the Senantiomer. The D51A mutant showed a ratio of 1.54 and hence a stronger preference for the Senantiomer. The W24F, W24Y and N310A mutants, however, displayed ratios $<1$ and therefore preference for the $R$-enantiomer.

Table 1

Apparent kinetic parameters of CtXR wild type and mutants for NADH-dependent reduction of racemic and (S)-2-phenylpropanal.

\begin{tabular}{|c|c|c|c|c|c|}
\hline & rac-2-phenylpropanal & & (S)-2-phenylpropanal & & $\begin{array}{l}\text { Ratio } \\
\text { specificity constants }\end{array}$ \\
\hline CtXR & $k_{\mathrm{cat}} / K_{\mathrm{m}, \mathrm{rac}}\left(\mathrm{s}^{-1} \mathrm{M}^{-1}\right)$ & $K_{\mathrm{m}, r a c}(\mu \mathrm{M})$ & $k_{\mathrm{cat}} / K_{\mathrm{m}, S}\left(\mathrm{~s}^{-1} \mathrm{M}^{-1}\right)$ & $K_{\mathrm{m}, S}(\mu \mathrm{M})$ & $\begin{array}{l}(S) \text {-aldehyde / } \\
\text { racemic aldehyde }\end{array}$ \\
\hline wild-type & 130 & 350 & 160 & 450 & 1.23 \\
\hline D51A & $28 \cdot 10^{3}$ & 170 & $43 \cdot 10^{3}$ & 120 & 1.54 \\
\hline W24F & $13^{\mathrm{a}}$ & n.a. & 12 & n.a. & 0.92 \\
\hline W24Y & $10^{\mathrm{a}}$ & n.a. & 9 & n.a. & 0.90 \\
\hline N310A & 88 & 280 & 68 & 330 & 0.77 \\
\hline N310D & no activity & no activity & no activity & no activity & - \\
\hline
\end{tabular}

Reduction of rac-2-phenylpropanal by isolated D51A CtXR

We used isolated CtXR D51A in bioreductions of $0.5 \mathrm{mM}$ rac-2-phenylpropanal. The substrate (log $P 2.11$, https://scifinder.cas.org/) displayed a maximal solubility of $0.5 \mathrm{mM}$ in buffer. Product concentrations and e.e. values obtained at enzyme concentrations between 240 and $0.6 \mathrm{U} / \mathrm{mL}$ are listed in Table 2. As expected, the product e.e. values increased with decreasing amounts of enzyme. Unexpectedly, reactions stopped after $2 \mathrm{~h}$ and maximal product concentrations of $120 \mu \mathrm{M}$ were achieved (for a time course see the Supplementary data). We suspected enzyme deactivation as cause of low conversions and used a whole-cell biocatalyst based on D51A CtXR in further experiments. 
Table 2

Conversions and product e.e.-values of rac-2-phenylpropanal reduction by isolated D51A CtXR. ${ }^{a}$

\begin{tabular}{|lll|}
\hline CEXR $(\mathrm{U} / \mathrm{mL})^{\mathrm{b}}$ & $(\mathrm{S})$-Phenylpropanol $(\mu \mathrm{M})$ & $\begin{array}{l}\text { e.e. }(\mathrm{S}) \text {-Phenylpropanol } \\
(\%)\end{array}$ \\
\hline D51A (240) & 25 & 23 \\
\hline D51A (20) & 16 & 38 \\
\hline D51A (3.4) & 11 & $\geq 99$ \\
\hline D51A (0.6) & 4 & $\geq 99$ \\
\hline aReaction time 2 h. $^{\text {b }}$ Measured with 0.5 mM rac-2-phenylpropanal. \\
\hline
\end{tabular}

Reduction of rac-2-phenylpropanal by E. coli co-expressing CtXR D51A and a yeast formate dehydrogenase

Bioreductions were accomplished by lyophilized and rehydrated biomass or cell-free supernatant of engineered $E$. coli. The highly hydrophobic substrate formed a second phase in the reaction buffer above its solubility limit. Stirring led to droplet formation that were stabilized against coalescence in the presence of lyophilized biomass or supernatant.

\section{0 mM rac-2-phenylpropanal}

Conversions and product e.e. values for the reduction of $100 \mathrm{mM}$ 2-phenylpropanal are summarized in Fig. 1. The amount of catalyst was varied between 4 and $40 \mathrm{~g}_{\mathrm{CDW}} / \mathrm{L}$. Comparison of lyophilized cells to cell-free supernatant used as catalyst was facilitated by using an equal amount of biomass for catalyst preparation in both cases. It has been previously shown that $>40 \%$ of the total biomass activity is found as extracellular enzymes and hence in the supernatant (14). Conversions were similar for biomass and supernatant reflecting the severely impaired cell integrity caused by biomass lyophilization. Only at a low biocatalyst concentration of $4 \mathrm{~g}_{\mathrm{CDW}} / \mathrm{L}$, the supernatant led to significantly lower conversion ( $30 \%$ lower). Supernatant and whole biomass showed equally high e.e. values of $95.3 \%$ at $4 \mathrm{~g}_{\mathrm{CDW}} / \mathrm{L}$. Product enantiopurity and conversions increased gradually with increasing biocatalyst load. Notably, the e.e. values obtained with the supernatant decreased more strongly than the e.e. values from reductions with the whole biomass. At a catalyst load equal to $40 \mathrm{~g} \mathrm{CDw} / \mathrm{L}$ the e.e. values were 27 and $46 \%$ for supernatant and whole biomass, respectively.

\section{Optimization of 2-phenylpropanal bioreduction}

Substrate concentration. Product concentration is the most important metric for bioprocesses to become compatible to chemical processes. Therefore, we increased the substrate concentration to $1 \mathrm{M}$ at varying catalyst concentrations (lyophilized, rehydrated biomass) (Fig. 2, Table 3). The effects of increased catalyst loading on conversion and e.e.-values showed a similar but less pronounced trend compared to bioreductions with $100 \mathrm{mM}$ substrate. A catalyst loading of $20 \mathrm{~g}$ CDw/L led to an e.e. value of $95 \%$ compromised by a conversion of $28 \%$. Increase of the catalyst loading to 40 $\mathrm{g}_{\mathrm{CDW}} / \mathrm{L}$ decreased the e.e. value to $93 \%$ at $56 \%$ conversion. A substrate concentration of $2 \mathrm{M}$ turned out as too high, only low conversions of $\sim 15 \%$ were reached (Table 3).

$\mathrm{NAD}^{+}$concentration. We added higher concentrations of the co-enzyme NAD ${ }^{+}$to further push the reaction towards full conversion. At 12 and $14 \mathrm{mM}$ of $\mathrm{NAD}^{+}$, conversions up to $99 \%$ were reached, again at e.e. values of 92-93\% (Fig. 2, Table 3).

Cyclodextrin addition. The addition of $75 \mathrm{mM}$ 2-hydroxypropyl- $\beta$-cyclodextrin has previously shown to boost bioreductions based on the used catalyst (14). Here, the addition of 38,75 or 115 mM 2-hydroxypropyl- $\beta$-cyclodextrin had no significant effect on bioreductions of 1 and $2 \mathrm{M} 2$-phenylpropanal (Table 3).

Fed-batch. The step-wise addition of substrate at 0,2 and $4 \mathrm{~h}$ to a total substrate concentration of $1 \mathrm{M}$ led to a $10 \%$ increase of conversion (Table 3 ).

\section{Recovery, isolated yield, reproducibility and by-products}

Leis et al. (20) previously suggested that hydrophobic substrates and products remain in the cell sludge of the used biocatalyst. Here, a high excess of ethyl acetate was required for product extraction prior to analysis. Obtained product concentrations in bioreductions of 1 and $2 \mathrm{M}$ were between 27 and $84 \%$ as shown in Table 3.

Recovery. Substrate/product loss in the biomass was found to be $<15 \%$ under the conditions used.

Reproducibility. Reaction replicates $(\mathrm{N}=7)$ of bioreductions with $40 \mathrm{~g} \mathrm{CDW} / \mathrm{L}$ and $6 \mathrm{mM} \mathrm{NAD}$ showed high reproducibility with a mean value of $62 \%$ product and a standard deviation of $4 \%$. The enantiomeric excess was $93.3 \pm 1.1 \%$ e.e. The formation of broad peaks prevented quantification of the aldehyde substrate by chiral, reversed-phase HPLC. We therefore analyzed bioreduction samples additionally by chiral GC-FID. 
Table 3

Conversions and product e.e.-values of rac-2-phenylpropanal reduction by lyophilized whole-cell catalyst. Effects of catalyst loading, substrate concentration, co-enzyme concentration and HBC-addition. ${ }^{a}$

\begin{tabular}{|c|c|c|c|c|c|}
\hline $\begin{array}{l}\text { Catalyst loading } \\
\left(\mathrm{g}_{\mathrm{CDW}} / \mathrm{L}\right)\end{array}$ & $\begin{array}{l}\text { rac-2-Phenylpropanal } \\
\text { (M) }\end{array}$ & $\begin{array}{l}\mathrm{NAD}^{+} \\
(\mathrm{mM})\end{array}$ & $\begin{array}{l}\mathrm{HBC} \\
(\mathrm{mM})\end{array}$ & (S)-Phenylpropanol (mM) & $\begin{array}{l}\text { e.e. (S)-Phenylpropanol } \\
(\%)\end{array}$ \\
\hline 20 & 1 & 3 & 0 & 276 & 95.1 \\
\hline 20 & 1 & 3 & 38 & 456 & 94.1 \\
\hline 20 & 1 & 3 & 75 & 494 & 93.3 \\
\hline 30 & 1 & 3 & 0 & 425 & 95.0 \\
\hline 30 & 1 & 3 & 38 & 496 & 94.2 \\
\hline 30 & 1 & 3 & 75 & 455 & 94.2 \\
\hline 40 & 1 & 3 & 0 & 564 & 93.4 \\
\hline 40 & 1 & 6 & 0 & 619 & 93.3 \\
\hline 40 & $1 \mathrm{M}$ fed-batch & 6 & 0 & 679 & 94.0 \\
\hline 40 & 1 & 8 & 0 & 732 & 94.1 \\
\hline 40 & 1 & 10 & 0 & 843 & 93.1 \\
\hline 40 & 1 & 12 & 0 & 839 & 92.9 \\
\hline 40 & 1 & 14 & 0 & 765 & 92.3 \\
\hline 40 & 1 & 6 & 38 & 634 & 94.3 \\
\hline 40 & 1 & 6 & 75 & 598 & 92.9 \\
\hline 40 & 1 & 6 & 115 & 592 & 92.5 \\
\hline 40 & 2 & 6 & 0 & 279 & 95.4 \\
\hline 40 & 2 & 6 & 38 & 306 & 93.4 \\
\hline 40 & 2 & 6 & 75 & 306 & 92.2 \\
\hline
\end{tabular}

By-products. The high reactivity of the substrate 2-phenylpropanal prompted investigation of possible by-products from chemical or bio-chemical reactions. It has been previously shown that acetophenone forms by oxygen-catalyzed degradation of rac-2-phenylpropanal (21). We found 7\% of acetophenone to be formed maximally and only trace amounts of its enzymatic reduction product in bioconversions of $1 \mathrm{M}$ phenylpropanal, using 40 $\mathrm{g}_{\mathrm{CDW}} / \mathrm{L}$ cells and $6 \mathrm{mM} \mathrm{NAD}^{+}(22)$. The substrate is also in a chemical equilibrium between rac-2-phenylpropanal and its corresponding hydrates. The previously reported enzymatic oxidation of 2-phenylpropanal hydrates to the corresponding carboxylic acids was not observed (12, 23). No substraterelated enol or aldol was found in detectable amounts (for data of NMR analyses see the Supplementary data).

Isolated yield. To confirm the identity of the obtained product, hydrophobic compounds were extracted from two reaction mixtures containing $1 \mathrm{M} 2$ phenylpropanol (reaction volume $2 \mathrm{~mL}, 40 \mathrm{~g}_{\mathrm{CDW}} / \mathrm{L}$ catalyst, $6 \mathrm{mM} \mathrm{NAD}{ }^{+}$). An analytical yield of $78 \%$ was determined by HPLC (product concentration).

The solvent and unreacted 2-phenylpropanal (bp $92-94^{\circ}$ ) were removed under reduced pressure. Product composition was $86 \% 2$-phenylpropanol, $7 \%$ acetophenone and $7 \%$ ethyl acetate (extractant) by ${ }^{1} \mathrm{H}$-NMR. No 2-phenylpropanal was found. An isolated yield of $64 \%$ was obtained (203 mg with a product content of $86 \%$ ). (For data of HPLC, GC and NMR analyses see the Supplementary data).

\section{Literature survey}

Reported enzymatic reductive kinetic resolution of rac-2-phenylpropanal studies are summarized in Table 4. Bioreductions of rac-2-phenylpropanal have been accomplished with free-floating enzymes (Table 4, entries 1-5, 8-10,12) and immobilized enzymes (entries 6,7,11). Previous studies aimed at probing bioreduction catalysts (free and immobilized oxidoreductases) in the kinetic resolution of rac-2-phenylpropanal (entries 4-11). Most enantioselective enzymes preferred the (S)-aldehyde (entries 1-8, 10). Rocha-Martín et al. (24) reported on an anti-prelog specific ADH from ThermuS thermophilus HB27 (entry 11). Dong et al. (8) accomplished the evolution of ADHs for the formation of ( $S$ )- and (R)-alcohols by directed evolution of an ADH from Thermoanaerobacter brockii that displayed moderate prelog-type selectivity (entries 8,9$)$. The used enzymes had to display not only high enantioselectivities but also sufficient stabilities in the presence of the substrate that can form adducts with groups on the enzymes (25). HLADH was used in most studies as it turned out to be enantioselective, stable in the presence of substrate up to a concentration of $165 \mathrm{mM}$, and useful in coupled substrate strategies (oxidation of cheap alcohols for NADH-recycling). All other examples of selective ADHs stem from thermophilic organisms and display intrinsically high stabilities towards adverse effects of the reaction media. Remarkably, the often-used host $E$. coli shows native activity towards 
2-phenylpropanal (entry 13). Buffered solutions containing water-soluble co-solvents (also used as sacrificial substrate for NADH-recycling) were used frequently. The aqueous phase was required for the racemisation of the substrate. Grunwald et al. (11) tested HLADH in organic solvent and used isopropylether with $0.5 \%$ buffer as reaction medium. A product concentration of $46 \mathrm{mM}$ with $95 \%$ e.e. was obtained, however at a conversion of $15 \%$ (entry 7). Others used bi-phasic solvents (entries 4 and 6). The highest published product concentration of $82 \mathrm{mM}$ was achieved in a buffer/isopropylether mixture (47:63) (entry 4). 
Table 4

Literature survey of enzymatic reductive kinetic resolution of rac-2-phenylpropanal

\begin{tabular}{|c|c|c|c|c|c|c|c|}
\hline Entry & $\begin{array}{l}\text { Bioreduction catalyst, } \\
\text { NAD(P)H-recycling strategy }\end{array}$ & $\begin{array}{l}\text { rac-2- } \\
\text { phenylpropanal }\end{array}$ & $\begin{array}{l}\text { Medium, } \\
\text { (auxiliary substrate) }\end{array}$ & $\begin{array}{l}\text { Product } \\
\text { (Conversion) }\end{array}$ & Enantiopurity & Aim of the study & Ref. \\
\hline & $\begin{array}{l}\text { Horse liver ADH (Zn- } \\
\text { containing ADH) }\end{array}$ & & & & & & \\
\hline 1 & $\begin{array}{l}\text { Free enzyme, } \\
\text { coupled substrate 1,4- } \\
\text { butanediol }\end{array}$ & $5 \mathrm{mM}$ & $\begin{array}{l}\text { Buffer pH 7.5, } 1 \% \text { v/v } \\
\mathrm{CH}_{3} \mathrm{CN}, \\
\text { (2.5 mM 1,4-butanediol) }\end{array}$ & $\begin{array}{l}5 \mathrm{mM} \\
(99 \%)\end{array}$ & $95 \%$ e.e. $S$ & $\begin{array}{l}\text { Probing the } \\
\text { enzyme's co- } \\
\text { enzyme recycling } \\
\text { ability using 1,4- } \\
\text { butanediol } \\
\text { oxidation to } \\
\text { lactone }\end{array}$ & 26 \\
\hline 2 & $\begin{array}{l}\text { Free enzyme, } \\
\text { coupled substrate ethanol }\end{array}$ & $0.5 \mathrm{mM}$ & $\begin{array}{l}\text { Buffer } \mathrm{pH} 7.5 \\
(0.5 \mathrm{M} \text { ethanol })\end{array}$ & $\begin{array}{l}0.38 \mathrm{mM} \\
(75 \%)\end{array}$ & $98 \%$ e.e. $S$ & $\begin{array}{l}\text { Investigation of } \\
\text { DKR including } \\
\text { substrate } \\
\text { racemization } \\
\text { velocity }\end{array}$ & $\begin{array}{l}27 \\
10\end{array}$ \\
\hline 3 & $\begin{array}{l}\text { Free enzyme, } \\
\text { phenylpropanal oxidation } \\
\text { for NADH-recycling }\end{array}$ & $75 \mathrm{mM}$ & $\begin{array}{l}\text { Buffer pH 7.5; } 4 \text { \% v/v } \\
\text { MTBE }\end{array}$ & $\begin{array}{l}23 \mathrm{mM} \\
(31 \%)\end{array}$ & $97 \%$ e.e. $S$ & $\begin{array}{l}\text { Investigation of } \\
\text { the biocatalytic } \\
\text { asymmetric } \\
\text { disproportionation } \\
\text { (biocatalytic } \\
\text { Cannizzaro } \\
\text { reaction) }\end{array}$ & $\begin{array}{l}12 \\
28\end{array}$ \\
\hline 4 & $\begin{array}{l}\text { Free enzyme, } \\
\text { coupled substrate ethanol }\end{array}$ & $165 \mathrm{mM}$ & $\begin{array}{l}\text { Buffer, } 63 \% \text { v/v } \\
\text { isopropylether, } \\
\text { (0.6 M ethanol) }\end{array}$ & $\begin{array}{l}82 \mathrm{mM} \\
(50 \%)\end{array}$ & $96 \%$ e.e. $S$ & $\begin{array}{l}\text { Probing the } \\
\text { enzyme's } \\
\text { enantioselectivity } \\
\text { and co-enzyme } \\
\text { recycling ability }\end{array}$ & 29 \\
\hline 5 & $\begin{array}{l}\text { Free enzyme, } \\
\text { coupled substrate ethanol }\end{array}$ & $30 \mathrm{mM}$ & $\begin{array}{l}\text { Buffer } \mathrm{pH} 8 \\
\text { (5\% v/v ethanol) }\end{array}$ & $\begin{array}{l}28 \mathrm{mM} \\
(93 \%)\end{array}$ & $93 \%$ e.e. $S$ & $\begin{array}{l}\text { One-pot, two-step } \\
\text { reaction: rac-2- } \\
\text { phenyl-1-propanol } \\
\text { oxidation to rac-2- } \\
\text { phenylpropanal } \\
\text { followed by } \\
\text { enantioselective } \\
\text { bioreduction } \\
\text { under dynamic } \\
\text { conditions. }\end{array}$ & 1 \\
\hline 6 & $\begin{array}{l}\text { Immobilized enzyme, } \\
\text { coupled substrate ethanol }\end{array}$ & $5 \mathrm{mM}$ & $\begin{array}{l}\text { Buffer } \mathrm{pH} 7.5,50 \text { \% v/v } \\
\text { hexane, } \\
(0.5 \mathrm{M} \text { ethanol })\end{array}$ & $\begin{array}{l}4.2 \mathrm{mM} \\
(84 \%)\end{array}$ & $>98 \%$ e.e. $S$ & $\begin{array}{l}\text { Characterization } \\
\text { of the } \\
\text { immobilized } \\
\text { catalyst }\end{array}$ & 30 \\
\hline 7 & $\begin{array}{l}\text { Immobilized enzyme, } \\
\text { coupled substrate ethanol }\end{array}$ & $300 \mathrm{mM}$ & $\begin{array}{l}\text { Isopropyl ether } \\
\text { (saturated with buffer), } \\
0.5 \% \text { buffer pH 7.0, } \\
\text { (1 M ethanol) }\end{array}$ & $\begin{array}{l}46 \mathrm{mM} \\
(15 \%)\end{array}$ & $95 \%$ e.e. $S$ & $\begin{array}{l}\text { Probing the } \\
\text { enzyme's } \\
\text { substrate scope } \\
\text { and } \\
\text { enantioselectivity } \\
\text { in organic solvent }\end{array}$ & 11 \\
\hline & $\begin{array}{l}\text { Thermostable ADHs } \\
\text { (enzyme superfamily) }\end{array}$ & & & & & & \\
\hline 8 & $\begin{array}{l}\text { Free Thermoanaerobacter } \\
\text { brockii LG296 ADH mutant } \\
\text { (Zn-containing ADH), } \\
\text { coupled substrate } \\
\text { isopropanol }\end{array}$ & $30 \mathrm{mM}$ & $\begin{array}{l}\text { Buffer pH 7.4, } \\
\text { (20\% v/v isopropanol) }\end{array}$ & $\begin{array}{l}23 \mathrm{mM} \\
(75 \%)\end{array}$ & $95 \%$ e.e. $S$ & $\begin{array}{l}\text { Development of } \\
\text { enantioselective } \\
\text { mutants }\end{array}$ & 8 \\
\hline 9 & $\begin{array}{l}\text { Free Thermoanaerobacter } \\
\text { brockii LG277 ADH mutant } \\
\text { (Zn-containing ADH), } \\
\text { coupled substrate } \\
\text { isopropanol }\end{array}$ & $10 \mathrm{mM}$ & $\begin{array}{l}\text { Buffer } \mathrm{pH} 7.4 \\
\text { (20\% v/v isopropanol) }\end{array}$ & $\begin{array}{l}7.5 \mathrm{mM} \\
(75 \%)\end{array}$ & $92 \%$ e.e. $R$ & $\begin{array}{l}\text { Development of } \\
\text { enantioselective } \\
\text { mutants }\end{array}$ & 8 \\
\hline 10 & $\begin{array}{l}\text { Free Sulfolobus solfataricus } \\
\text { ADH-10 (Zn-containing } \\
\text { ADH), coupled substrate } \\
\text { ethanol }\end{array}$ & $5 \mathrm{mM}$ & $\begin{array}{l}\text { Buffer } \mathrm{pH} 9 \\
\text { (5\% ethanol) }\end{array}$ & $\begin{array}{l}3.7 \mathrm{mM} \\
(74 \%)\end{array}$ & $98 \%$ e.e. $S$ & $\begin{array}{l}\text { Probing the } \\
\text { enzyme's } \\
\text { substrate scope } \\
\text { and } \\
\text { enantioselectivity }\end{array}$ & 9 \\
\hline
\end{tabular}




\begin{tabular}{|c|c|c|c|c|c|c|c|}
\hline Entry & $\begin{array}{l}\text { Bioreduction catalyst, } \\
\text { NAD(P)H-recycling strategy }\end{array}$ & $\begin{array}{l}\text { rac-2- } \\
\text { phenylpropanal }\end{array}$ & $\begin{array}{l}\text { Medium, } \\
\text { (auxiliary substrate) }\end{array}$ & $\begin{array}{l}\text { Product } \\
\text { (Conversion) }\end{array}$ & Enantiopurity & Aim of the study & Ref. \\
\hline \multirow[t]{2}{*}{11} & $\begin{array}{l}\text { Immobilized Thermus } \\
\text { thermophilus ADH (short- } \\
\text { chain } \\
\text { dehydrogenases/reductase), } \\
\text { coupled enzyme yeast } \\
\text { formate dehydrogenase }\end{array}$ & $1 \mathrm{mM}$ & $\begin{array}{l}\text { Buffer pH 7, } 5 \% \text { v/v } \\
\mathrm{CH}_{3} \mathrm{CN} \\
\text { (0.1 M formic acid) }\end{array}$ & $\begin{array}{l}1 \mathrm{mM} \\
(100 \%)\end{array}$ & $71 \%$ e.e. $R$ & $\begin{array}{l}\text { Characterization } \\
\text { of the } \\
\text { immobilized } \\
\text { catalyst }\end{array}$ & 24 \\
\hline & Origin of enzyme not stated & & & & & & \\
\hline \multirow[t]{2}{*}{12} & $\begin{array}{l}\text { Free Evo-1.1.200 from } \\
\text { Evocatal } \\
\text { coupled substrate ethanol }\end{array}$ & $30 \mathrm{mM}$ & $\begin{array}{l}\text { Buffer } \mathrm{pH} 9 \\
\text { (5\% v/v isopropanol) }\end{array}$ & $\begin{array}{l}29 \mathrm{mM} \\
(95 \%)\end{array}$ & $89 \%$ e.e. $R$ & $\begin{array}{l}\text { One-pot, two-step } \\
\text { reaction: rac-2- } \\
\text { phenyl-1-propanol } \\
\text { oxidation to rac-2- } \\
\text { phenylpropanal } \\
\text { followed by } \\
\text { enantioselective } \\
\text { bioreduction } \\
\text { under dynamic } \\
\text { conditions. }\end{array}$ & 1 \\
\hline & Whole-cell catalyst & & & & & & \\
\hline 13 & $\begin{array}{l}\text { E. coli JM109, } \mathrm{NAD}(\mathrm{P}) \mathrm{H}- \\
\text { recycling by native microbial } \\
\text { metabolism }\end{array}$ & $22 \mathrm{mM}$ & $\begin{array}{l}\text { M9 medium, } 30 \% \mathrm{v} / \mathrm{v} \\
\text { organic phase }(9: 1 \\
\text { isopropylether:isooctane) }\end{array}$ & $\begin{array}{l}4.5 \mathrm{mM} \\
(48 \%)\end{array}$ & $\begin{array}{l}\sim 50 \% \text { e.e. (? } \\
\text { unknown) }\end{array}$ & $\begin{array}{l}\text { Probing the host } \\
\text { background } \\
\text { activity }\end{array}$ & 31 \\
\hline 14 & $\begin{array}{l}\text { CtXR D51A mutant (aldo- } \\
\text { keto reductase) } \\
\text { coupled enzyme yeast } \\
\text { formate dehydrogenase }\end{array}$ & $1000 \mathrm{mM}$ & $\begin{array}{l}\text { Buffer } \mathrm{pH} 7.5 \\
\text { (1.05 M formic acid) }\end{array}$ & $\begin{array}{l}843 \mathrm{mM} \\
\text { (98.8\%, but } \\
\text { product and } \\
\text { substrate } \\
\text { loss) }\end{array}$ & $93.1 \%$ e.e. $S$ & $\begin{array}{l}\text { Process } \\
\text { optimization } \\
\text { regarding } \\
\text { enantiopurity and } \\
\text { yield }\end{array}$ & $\begin{array}{l}\text { This } \\
\text { work }\end{array}$ \\
\hline
\end{tabular}

\section{Discussion}

Catalyst development

\section{Activities of CtXR variants}

Wild-type $C t$ XR showed a catalytic efficiency of $130 \mathrm{~s}^{-1} \mathrm{M}^{-1}$ with a low $K_{\mathrm{m}}$ of $350 \mu \mathrm{M}$ and corresponding $k_{\text {cat }}$ of $0.05 \mathrm{~s}^{-1}$ for the reduction of rac-2phenylpropanal.

Asp-51. Comparison of CtXR variants in the reduction of 2-phenylpropanal (Table 1) showed that replacement of the charged Asp-51 by alanine improved the enzyme's activity substantially. The catalytic efficiency increased 215-fold for racemic 2-phenylpropanal and 270-fold for the (S)-aldehyde compared to the wild-type. Likewise, the catalytic efficiency for reduction of o-chloroacetophenone was improved 13-times by the D51A mutation (14) whereas a 50 -fold decrease was observed for the conversion of xylose (19). Our results stressed the notion made by Kavanagh et al. (18) that Asp-51 in $\mathrm{CtXR}$ contributes the most to the relative polarity of the binding site and hence specificity for sugar substrates. Replacement of aspartate by alanine turned out as general strategy to improve CtXR's efficiency towards hydrophobic substrates.

Trp-24. Reduced enzyme activity towards 2-phenylpropanal by removal of the bulky Trp24 confirmed that the presence of Trp-24 is important for the efficient conversion of aldehydes $(13,19)$.

Low solubilities of hydrophobic substrates generally impede the determination of kinetic parameters. 2-Phenylpropanal showed extremely low solubility $(0.5 \mathrm{mM})$ in buffered medium. Small $K_{\mathrm{m}}$-values obtained with $C t \mathrm{XR}$ variants enabled the comparison of $C t$ XR variants (especially for the D51A mutant with $K_{\mathrm{m}}$-values of below $200 \mu \mathrm{M}$ for the racemic aldehyde and the (S)-aldehyde). The comparability to other oxidoreductases that display higher $K_{\mathrm{m}}{ }^{-}$ values remained, however, problematic. D51A CtXR had a $\sim 40$-fold higher $k_{\text {cat }}$-value and a $\sim 30$-fold smaller $K_{\mathrm{m}}$-value for the racemic substrate compared to published values for Thermoanaerobacter brockii ADH variants (8).

\section{Enantioselectivities of CtXR variants}

The enantioselectivity of an enzyme is defined by the ratio of catalytic efficiencies for the two enantiomers $\left(\mathrm{E}=\left(k_{\mathrm{cat}} / K_{\mathrm{m}, \mathrm{S}}\right) /\left(k_{\mathrm{cat}} / K_{\mathrm{m}, \mathrm{R}}\right), 32\right)$. In the present case, the determination of the catalytic efficiencies of enantiopure $(S)$ and $(R)$-aldehydes was compromised by in situ substrate racemization. Published racemization velocities of 2-phenylpropanal were $75 \cdot 10^{-6} \mathrm{~s}^{-1}\left(k_{\text {rac }}\right)$, equal to half-lives of $\sim 2 \mathrm{~h}\left(\mathrm{t}_{1 / 2}\right)(27)$. The relatively slow racemization should generally enable determination of $k_{\mathrm{cat}} / K_{\mathrm{m} \text {,enantiomer }}$ with enzymatic assays lasting 5 minutes. We have, however, experienced slow racemization of the pure enantiomers during freeze-storage $\left(-18^{\circ} \mathrm{C}\right)$. Hence, enantioselectivities expressed as $\left(k_{\mathrm{cat}} / K_{\mathrm{m}, \mathrm{S}}\right) /\left(k_{\mathrm{cat}} / K_{\mathrm{m}, \text { rac }}\right)$ in Table 1 show approximate values that are still useful to guide enzyme selection and reaction optimization. The wild-type showed preference for the ( $S$ )-aldehyde (ratio of 1.23 ). 
Asp-51, Asn-310. The D51A mutant showed a stronger preference for the S-enantiomer (a ratio of 1.54) and the N310A for the R-enantiomer (ratio of 0.77). Asp-51 and Asn-310 are on opposite sides of the substrate binding pocket (Fig. 3). Asp-51 is suggested to interact with the natural substrate xylose at C3, C4 and C5 hydroxyls, Asn-310 with the C2 hydroxyl (18). A docking of wild-type CtXR (in complex with NAD+; 33) with xylose and (S)- and $(R)$-2-phenylpropanal was made (Fig. 3AB). Replacement of Asp-51 by alanine might facilitate interaction between the alanine and the phenyl-ring of (S)-2-phenylpropanal (Fig. 3C). After replacement of Asn-310 by alanine, interaction between alanine and the phenyl-ring chain of ( $R$ )-2-phenylpropanal becomes plausible for N310A (Fig. 3D). Docking results supported findings from the kinetic studies: D51A mutation improved transition state stabilization of the $(S)$-aldehyde while N310A mutation improved stabilization of the $(R)$-aldehyde, respectively.

Trp-24. W24F and W24Y mutants showed $\left(k_{\text {cat }} / K_{\mathrm{m}, \mathrm{S}}\right) /\left(k_{\mathrm{cat}} / K_{\mathrm{m} \text { rac }}\right)$ ratios of $\sim 0.91$ (Table 1$)$ along with approximately $\geq 10$-fold reduction in catalytic efficiencies. Lower activities (with higher $K_{\mathrm{m}}$-values) and preference for the $(R)$-aldehyde might indicate poorer interaction between the aromatic rings of phenylalanine or tyrosine and the aldehyde proton of the $(S)$-aldehyde. In conclusion, the D51A turned out as CtXR variant with improved catalytic efficiency and enantioselectivity.

\section{Catalyst stabilization}

$\mathrm{CtXR}$ is generally known as a relative labile enzyme and half-lives in the presence of 5 to $10 \mathrm{mM}$ o-chloroacetophenone and 1-(2-chlorophenyl)ethanol shrunk to $<3 \mathrm{~min}$. In the case of $o$-chloroacetophenone and its reaction product the unfavourable log $P$-values $(\sim 2)$ were held responsible for fast enzyme deactivation. Use of the enzyme as catalytic oxidoreductase in whole-cell catalysts (E. coli, $S$. cerevisiae, $C$. tenuis) had previously shown to stabilize the enzyme substantially and product concentrations were improved >10-fold (34). Reactive aldehydes are known to form adducts with proteins at the lysine, histidine and cysteine side chains (25). Enzyme deactivation by 2-phenylpropanal might hence follow different mechanisms compared to o-chloroacetophenone. Use of the whole cells provided an extreme case of catalyst stabilization in the presence of 2-phenylpropanal: The isolated enzyme was deactivated by $0.5 \mathrm{mM}$ aldehyde whereas the whole-cell catalyst and the supernatant thereof were able to tolerate and convert $1 \mathrm{M}$ of the substrate. Stabilization of the catalytic enzyme by whole-cells and cell debris was previously reported for the synthesis of $(R)$ phenylacetylcarbinol from benzaldehyde and pyruvate by a Candida utilis pyruvate decarboxylase (35). The stabilization was ascribed to membrane components that form a microenvironment around the enzyme and thereby decrease aldehyde transfer to the enzyme and protect the enzyme from deactivation at the aqueous/organic interphase.

\section{Product-enantiopurity and concentration}

In the case of an enzyme that converts one enantiomer much faster than the other, the first percentages of product will show high enantiopurity, whereas a decrease is expected in the course of the reaction (expressed in the Chen equation, 32). A dependence of product enantiopurity on reaction progress, especially at high enzyme loading, was experienced by us and others despite DKR conditions. Substrate racemization velocity was identified as main limitation towards high product enantiopurity $(12,28)$. Here, substrate-to-catalyst ratio turned out as main factor determining product enantiopurity. The e.e. value of the product showed a strong dependence on substrate-to-catalyst ratio below $3.4 \mathrm{~g}_{\text {substrate }} / \mathrm{g}_{\mathrm{CDW}}$. At $3.4 \mathrm{~g}$ substrate $/ \mathrm{g}_{\mathrm{CDW}}$ product enantiopurities of $\sim 94 \%$ were obtained at $100 \mathrm{mM}$ and $1 \mathrm{M}$ 2-phenylpropanal concentrations and e.e. values were only slightly increasing at higher substrate-to-catalyst ratios (Fig. 4).

We previously stated a maximal catalyst loading of 40 to $50 \mathrm{~g} \mathrm{CDw} / \mathrm{L}$ in bioreductions to minimize product loss of hydrophobic substances in the biomass fraction during downstream processing (36). The minimally applicable substrate-to-biocatalyst ratio of $3.4 \mathrm{~g}_{\text {substrate }} / \mathrm{g}_{\mathrm{CDW}}$ gives a substrate loading of 1 to $1.25 \mathrm{M}$. Higher substrate-to-biocatalyst ratios (2 M substrate at $40 \mathrm{~g}_{\mathrm{CDW}} / \mathrm{L}$, or $1 \mathrm{M}$ substrate at $20-30 \mathrm{~g}$ formation. The catalyst was fully deactivated during the reaction time of $48 \mathrm{~h}(14)$. Elevated $\mathrm{NAD}^{+}$concentrations of $6-14 \mathrm{mM}$ were used to fully exploit the catalytic activity of the coupled oxidoreductase system. In the present case, a compromise between enantiopurity and conversion had to be found. Limiting factors are substrate racemization velocity, catalyst loading and catalyst stability.

\section{Conclusion}

Optimization of an enzymatic dynamic reductive kinetic resolution of racemic 2-phenylpropanal towards 843 mM (S)-2-phenylpropanol was accomplished. The multilevel engineering included engineering of the wild-type CtXR for improved enzyme activity and enantioselectivity, use of an $E$. coli whole-cell catalyst for enzyme stabilization and coenzyme recycling and optimization of the substrate-to-catalyst ratio.

Enzyme level. Several substrate-binding mutants based on a xylose-binding model (18) were investigated. The D51A CtXR variant showed high selectivity and catalytic activity towards (S)-2-phenylpropanal in initial rate measurements. However, fast enzyme deactivation was experienced in the bioreduction of $0.5 \mathrm{mM}$ racemic 2-phenylpropanal. A literature survey revealed 9 examples of bioreductions catalyzed by free enzymes (and 3 examples of immobilized enzymes), all of which were either HLADH or enzymes from thermophilic hosts. The low number of reported enzymes and the low concentrations of obtained product stressed a general deactivating effect of the reactive aldehyde on enzymes.

Whole-cell level. The whole-cell catalyst based on D51A CtXR showed, much to our delight, high stability in the presence of $1 \mathrm{M}$ phenylpropanal. Our results indicate a strong protecting effect by the whole-cell catalyst (and the supernatant thereof). We used lyophilized and rehydrated $E$. coli coexpressing D51A CtXR and yeast formate dehydrogenase as catalyst.

Page $9 / 17$ 
Reaction level. The most important factor to obtain high enantiopurities and product concentrations was the ratio of substrate to catalyst (Fig. 1, Fig. 4, Table 3). The amount of $\mathrm{NAD}^{+}$was the second most important factor. Catalyst and co-enzyme concentration directly affected reduction rate. High reduction velocity led to high conversions but also lower product enantiopurities. The conversion with a catalyst loading of $40 \mathrm{~g}_{\mathrm{CDW}}, 10 \mathrm{mM} \mathrm{NAD}^{+}$and 1 M substrate represented a compromise to obtain (S)-phenylpropanol in $93 \%$ e.e. enantiopurity and 843 mM product concentration (Table 4, entry 14 ). We explain higher e.e. -values obtained with the whole biomass as compared to the supernatant by the presence of cells and cell debris (Fig. 1). The substrate was added in concentrations far above its solubility limit of $0.5 \mathrm{mM}$ and hence formed a second phase. The presence of cellular components led to a very fine dispersion of the rac-2-phenylpropanal in form of an oil-in-water emulsion (37). Organic/aqueous phase mass transfer was facilitated and led to a scenario where used substrate (mainly $S$-form) was replenished fast by the racemic substrate. As a result, the ( $S$ )-aldehyde was constantly supplied and consumed, the (R)-aldehyde supplied and (slowly) racemized. Use of a stable and selective enzyme (D51A CtXR) enabled the synthesis of a highly enantiopure product under these conditions.

\section{Materials And Methods}

Chemicals, enzymes and strains

\section{Chemicals}

Racemic 2-phenylpropanal (98\%), racemic 2-phenylpropanol (97\%), acetophenone (99\%) and racemic 1-phenylethanol ( $\geq 98 \%)$ were purchased from Sigma-Aldrich/Fluka (Vienna, Austria), (S)-2-phenylpropanal (95\%) and (R)-2-phenylpropanal (95\%) were from Accela (Prien - Chiemsee, Germany), 2-

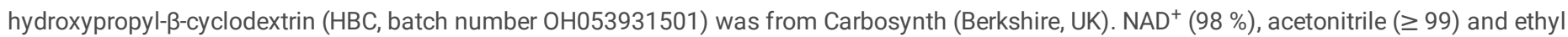
acetate $(\geq 99,9 \%$ ) were from Roth (Karlsruhe, Germany). Other chemicals were from Sigma-Aldrich/Fluka or Roth, and were of the highest purity available. Materials for genetic experiments were reported elsewhere (19).

\section{Enzymes}

The used reductases were wild-type and single-point mutants of Candida tenuis xylose reductase (CtXR wild-type GenBank ID AF074484). Site-directed mutagenesis and amino acid insertion for CtXR mutants D51A, W24F, W24Y, N310A, N310D were carried out by using inverse PCR as described elsewhere (19). Production of CtXR (wild-type and mutants D51A, W24F, W24Y, N310A, N310D) was previously described (19).

\section{Whole-cell biocatalyst}

An E. coli Rosetta2 strain co-expressing CtXR D51A and CbFDH (GenBank ID AJ011046) was used. Whole-cell biocatalyst production was previously described by Rapp et al. (14). The biomass was frozen at $-20^{\circ} \mathrm{C}$, lyophilized (Christ a 1-4 lyophilizer from Braun Biotech International) and stored at $-20^{\circ} \mathrm{C}$.

Total enzyme activities of the biomass (extracellular and intracellular enzymes). Activities of the whole biomass (extracellular and intracellular enzymes), measured after cell lysis and protein extraction for xylose reductase and formate dehydrogenase were $1590 \mathrm{U} / \mathrm{g}_{\mathrm{CDW}}$ and $154 \mathrm{U} / \mathrm{g}_{\mathrm{CDW}}$, respectively (14).

Enzyme activities of the supernatant (extracellular enzymes). The rehydrated biomass was centrifuged and the activities of xylose reductase and formate dehydrogenase that had leaked out of the cells were determined to $512 \mathrm{U} / \mathrm{g}_{\mathrm{CDW}}$ and $72 \mathrm{U} / \mathrm{g}_{\mathrm{CDW}}$, respectively, in the supernatant. The procedures for activity determination were described earlier (14).

\section{Enzyme-substrate docking}

PyMOL Molecular Graphics System (Open-Source, Schrödinger, LLC) was used for enzyme/ligand structure depictions. Ligand docking experiments were performed in YASARA (YASARA Biosciences $\mathrm{GmbH}$, Vienna, Austria) using Autodock Vina (38) with standard parameters.

Enzyme kinetics

\section{Steady-state enzyme kinetics}

Kinetic parameters of NADH-dependent 2-phenylpropanal reduction by CtXR variants were determined spectrophotometrically as described earlier (19). Solubility of 2-phenylpropanal in water was elevated to $0.5 \mathrm{mM}$ by addition of $25 \% \mathrm{v} / \mathrm{v}$ DMSO. Substrate solutions were freshly prepared and immediately used to avoid non-enzymatic decomposition and, with (S)-2-phenylpropanal, racemization in aqueous solution. A typical measurement period was 5 minutes. Non-specific background activity was considered by measuring blank activities. The added DMSO had no effect on the enzyme's activity with the natural substrate D-xylose.

\section{Bioreductions of racemic 2-phenylpropanal Reduction by the isolated D51A CtXR}


Racemic 2-phenylpropanal was dissolved in DMSO prior to dilution into $50 \mathrm{mM}$ potassium phosphate buffer, $\mathrm{pH} 7.0$ to a final DMSO concentration of $25 \%$. The substrate (final concentration $0.5 \mathrm{mM}$ ) was incubated at $25^{\circ} \mathrm{C}$ in the presence of $0.1 \mathrm{mM}$ excess [NADH] and D51A CtXR for 2 hours. For timecourse analysis, samples $(100 \mu \mathrm{L}$ ) were taken from the reaction mixtures (final reaction volume $1.5 \mathrm{~mL}$ ) at specified timepoints. All samples were diluted 1:1 with acetonitrile and centrifuged prior to analysis by chiral HPLC.

\section{Whole-cell bioreduction}

Lyophilized cells were re-hydrated in potassium phosphate buffer $(100 \mathrm{mM}, \mathrm{pH} 6.2$, re-hydration volume $\leq 50 \% \mathrm{v} / \mathrm{v}$ of the total bioreduction mixture) in the presence of $\mathrm{NAD}^{+}(3-14 \mathrm{mM})$ and sodium formate (50 mM excess on [substrate]) using $2 \mathrm{~mL}$ Eppendorf tubes. The tubes were placed on a thermomixer for $30 \mathrm{~min}$ at $25^{\circ} \mathrm{C}$ and $1400 \mathrm{rpm}$. In case of $\mathrm{HBC}$-aided conversions, cyclodextrins were weighed out separately in Eppendorf tubes followed by adding rac-2-phenylpropanal and $50 \mu \mathrm{L}$ buffer. Tubes were vortexed vigorously for complexation of substrate and HBC. Afterwards, rehydrated cells were combined with $\mathrm{HBC}$ /substrate complexes and filled up to a total working volume of $1 \mathrm{~mL}$. Alternatively, substrate was added directly to the re-hydrated cells if no HBC was applied. Eppendorf tubes were sealed with parafilm and vortexed until emulsification was reached. The mixtures were reacted for 24 or $48 \mathrm{~h}$ at room temperature using an end-over-end rotator (30 rpm). All samples were prepared in duplicates.

Fed-batch. The fed-batch bioreductions started as batch reactions with $330 \mathrm{mM}$ substrate, $6 \mathrm{mM} \mathrm{NAD}{ }^{+}$and $40 \mathrm{~g} \mathrm{CDW} / \mathrm{L}$. $50 \mu \mathrm{L}$ rac-2-phenylpropanal were fed after 2 and $4 \mathrm{~h}$ to a total substrate concentration of $1 \mathrm{M}$. The reaction was carried out for $48 \mathrm{~h}$. Fed-batch experiments were performed in duplicates.

Product isolation. Two bioreduction mixtures ( $1 \mathrm{~mL}$ reaction volume each) of $1 \mathrm{M}$ 2-phenylpropanal, $40 \mathrm{~g} \mathrm{CDW} / \mathrm{L}$ and $6 \mathrm{mM} \mathrm{NAD}+$ were pooled after incubation for $48 \mathrm{~h}$. The hydrophobic reaction compounds were extracted by four consecutive extraction steps using $1 \mathrm{v} / \mathrm{v}$ ethyl acetate per step. The pooled organic phase was evaporated under reduced pressure (Heidolph Laborota 4001 , Schwabach, Germany) at $40^{\circ} \mathrm{C}$. The final weight of the sample was determined.

Substrate/product recovery. For recovery experiments at substrate/product concentrations of $1 \mathrm{M}$, reaction mixtures containing 20 or $40 \mathrm{~g}$ CDw/L catalyst were prepared without adding $\mathrm{NAD}^{+}$. The samples were incubated applying conditions used for biotransformations and extracted following the procedure described in Sect. 2.4.1. Substrate/product recovery was performed in duplicates.

\section{Cell-free bioreduction}

Lyophilized cells $(40 \mathrm{mg})$ were re-hydrated for $30 \mathrm{~min}$ in $1 \mathrm{~mL}$ potassium phosphate buffer $(100 \mathrm{mM}, \mathrm{pH} 6.2)$ at $1400 \mathrm{rpm}$ and $25^{\circ} \mathrm{C}$ on a thermomixer followed by centrifugation $\left(13.2 \mathrm{k} \mathrm{rpm} ; 10 \mathrm{~min} ; 25^{\circ} \mathrm{C}\right)$. The supernatant was isolated and either applied directly or diluted $1 / 2,1 / 4$ or $1 / 10$ corresponding to the activity of 40, 20, 10 or $4 \mathrm{gcdw} / \mathrm{L}$. rac-2-phenylpropanal $(100 \mathrm{mM})$, sodium formate $(150 \mathrm{mM})$ and NAD+ $(6 \mathrm{mM})$ were added afterwards. All mixtures were adjusted to $1 \mathrm{~mL}$ and placed on an end-over-end rotator (30 rpm) for $24 \mathrm{~h}$. All samples were prepared in duplicates.

\section{Analytical methods}

\section{Sample preparation from whole-cell or cell-free bioreductions}

For HPLC and GC analyses, ethyl acetate $(1 \mathrm{~mL})$ was added to $1 \mathrm{~mL}$ of a reaction performed in $2 \mathrm{~mL}$ Eppendorf tubes. The tubes were vortexed followed by transferring the mixture into $15 \mathrm{~mL}$ Sarstedt tubes. Tubes were filled up to $10 \mathrm{~mL}$ with ethyl acetate, vortexed and centrifuged for $15 \mathrm{~min}, 25^{\circ} \mathrm{C}$ and $3220 \mathrm{~g}$ for extraction. Final dilutions in ethyl acetate contained $5 \mathrm{mM}$ substrate/product. For NMR analyses, substrate/product present in ethyl acetate after extraction was transferred into round-flasks and evaporated under reduced pressure. The isolated substrate/product was directly diluted in deuterated methanol ( $20 \mu \mathrm{L}$ substrate/product $+680 \mu \mathrm{L}$ solvent).

\section{Chiral HPLC analysis}

HPLC analysis was performed using a Merck-Hitachi LaChrom HPLC system equipped with a Merck L-7490 RI detector, an L-7400 UV-detector, a reversed phase Chiralpak ${ }^{\circledR}$ AD-RH column (from Daicel, obtained at Sigma Aldrich, Austria, Vienna) and a thermo-stated column oven (40 ${ }^{\circ} \mathrm{C}$ ). The mobile phase used contained $25 \%$ acetonitrile in $\mathrm{ddH}_{2} \mathrm{O}$. A flowrate of $30 \mathrm{~mL} / \mathrm{min}$ was applied. HPLC standards were prepared deploying racemic product in a range of $0.1,0.5,1,5,10 \mathrm{mM}$. Peak areas at corresponding retention times were used to calculate concentrations. The enantiomeric excess of the major product $(S)$-2-phenylpropanol was calculated by e.e. $=(S$-alcohol $-R$-alcohol $) /(S$-alcohol $+R$-alcohol). Retention times and chromatograms of authentic standards (main products ((S)-2-phenylpropanol, $(R)$-2-phenylpropanol), by-products (acetophenone, phenylethanol) were summarized in the Supplementary data. The aldehydes gave broad peaks and were quantified by GC-FID.

\section{Chiral GC-FID analysis}

GC analysis was performed on an Agilent 7890A GC with FID detection (12). Carrier gas was $\mathrm{H}_{2}$, the chiral column was a Hydrodex®- $\beta$-TBDAc column with $25 \mathrm{~m}$ length and an inner diameter of $0.25 \mathrm{~mm}$ (from Macherey-Nagel obtained from FisherScientific, Austria, Vienna). The injection volume was 5 $\mu \mathrm{L}$, the inlet temperature $230^{\circ} \mathrm{C}$, the split ratio $50: 1$ and the flow $1 \mathrm{~mL} / \mathrm{min}$, the detector temperature $250^{\circ} \mathrm{C}$. The following temperature program was used for separation of analytes: $110^{\circ} \mathrm{C} /$ hold $10 \mathrm{~min} ; 2^{\circ} \mathrm{C}$ per min to $123^{\circ} \mathrm{C} / \mathrm{hold} 3 \mathrm{~min} ; 10^{\circ} \mathrm{C}$ per min to $200^{\circ} \mathrm{C} / \mathrm{hold} 1 \mathrm{~min}$. Retention times and chromatograms of authentic standards (main products $((S)$-2-phenylpropanol, $(R)$-2-phenylpropanol), substrate $((S)$-2-phenylpropanal, $(R)$-2phenylpropanal) by-products (acetophenone, phenylethanol) are summarized in the Supplementary data. 


\section{NMR analysis}

${ }^{1} \mathrm{H}$-NMR spectra of isolated substrate/product from biotransformations (78 \% conversion) were recorded using a $300 \mathrm{MHz}$ Bruker $\mathrm{NMR}$ unit (300 MHz for $\left.{ }^{1} \mathrm{H}\right)$ at $300 \mathrm{~K}$. Chemical shifts $(\delta)$ were depicted in ppm relative to the resonance of the solvent (MeOD or DMSO- $\left.\mathrm{d}_{6}\right)$.

\section{Declarations}

\section{Ethics approval and consent to participate}

Not applicable.

\section{Consent for publication}

Not applicable.

\section{Availability of data and materials}

The datasets used and/or analysed during the current study are available in the Supplementary data and from the corresponding author on reasonable request.

\section{Competing interests}

The authors declare that they have no competing interests.

\section{Funding}

This work was supported by the Federal Ministry of Economy, Family and Youth (BMWFJ), the Federal Ministry of Traffic, Innovation and Technology (BMVIT), the Styrian Business Promotion Agency, SFG, the Standortagentur Tirol and ZIT-Technology Agency of the City of Vienna through the COMETFunding Programme (Comet K2) managed by the Austrian Research Promotion Agency FFG.

\section{Authors' contributions}

CR performed/analyzed bioreduction experiments and was involved in experimental design and manuscript preparation. SP-M performed experiments with isolated enzymes (kinetics, bioreductions). ET was involved in experimental design and bioreduction analyses. BN made contributions to studyconception, interpretation of data and revised the manuscript. RK concepted the study, contributed to the design of experiments, interpreted the data and drafted the manuscript. All authors read and approved the final manuscript.

\section{Acknowledgements}

We thank Drs. Alexander Denning and Alexander Lepak for discussions and support with GC and ${ }^{1} \mathrm{H}-\mathrm{NMR}$ analysis.

\section{References}

1. Díaz-Rodríguez A, Ríos-Lombardía N, Sattler JH, Lavandera I, Gotor-Fernández V, Kroutil W, Gotor V. Deracemisation of profenol core by combining laccase/TEMPO-mediated oxidation and alcohol dehydrogenase-catalysed dynamic kinetic resolution. Catal Sci Technol. 2015;5:1443-1446; doi:10.1039/C4CY01351D.

2. Abate A, Brenna E, Fuganti C, Gatti FG, Giovenzana T, Malpezzi L, Serra S. Chirality and fragrance chemistry: stereoisomers of the commercial chiral odorants Muguesia and Pamplefleur. J Org Chem. 2005;70:1281-90; doi:10.1021/jo048445j.

3. Scognamiglio J, Jones L, Letizia CS, Api AM. Fragrance material review on $\beta$-methylphenethyl alcohol. Food Chem Toxicol. 2012;50:199-203; doi.org/10.1016/j.fct.2011.10.023.

4. Kourist R, Domínguez de María P, Miyamoto K. Biocatalytic strategies for the asymmetric synthesis of profens - recent trends and developments. Green Chem. 2011;13:2607-2618; doi:0.1039/C1GC15162B.

5. Carvalho PO, Cass QB, Calafatti SA, Contesini FJ, Bizaco R. Review- Alternatives for the separation of drug enantiomers: ibuprofen as a model compound. Braz J Chem Eng. 2006;23:291-300; doi:10.1590/S0104-66322006000300003.

6. Koul S, Parshad R, Taneja SC, Qazi GN. Enzymatic resolution of naproxen. Tetrahedron: Asymmetry. 2003;14:2459-2465; doi:10.1016/S09574166(03)00492-0.

7. Steenkamp L, Brady D. Optimisation of stabilised carboxylesterase NP for enantioselective hydrolysis of naproxen methyl ester. Process Biochem. 2008;43:1419-1426; doi:0.1016/j.procbio.2008.09.001.

8. Dong Y, Yao P, Cui Y, Wu Q, Zhu D, Li G, Reetz MT. Manipulating the stereoselectivity of a thermostable alcohol dehydrogenase by directed evolution for efficient asymmetric synthesis of arylpropanols. Biol Chem. 2019;400:313-321; doi:10.1515/hsz-2018-0299. 
9. Friest JA, Maezato Y, Broussy S, Blum P, Berkowitz DB. Use of a robust dehydrogenase from an archael hyperthermophile in asymmetric catalysis-dynamic reductive kinetic resolution entry into (S)-Profens. J Am Chem Soc. 2010;132:5930-5931; doi:10.1021/ja910778p.

10. Giacomini D, Galletti P, Quintavalla A, Gucciardo G, Paradisi F. Highly efficient asymmetric reduction of arylpropionic aldehydes by Horse Liver Alcohol Dehydrogenase through dynamic kinetic resolution. Chem Commun. 2007;4038-4040; doi:10.1039/B712290J.

11. Grunwald J, Wirz B, Scollar MP, Klibanov AM. Asymmetric oxidoreductions catalyzed by alcohol dehydrogenase in organic solvents. J Am Chem Soc. 1986;108:6732-6134; doi:10.1016/s0958-1669(03)00074-0.

12. Tassano E, Faber K, Hall M. Biocatalytic parallel interconnected dynamic asymmetric disproportionation of a-substituted aldehydes: Atom-efficient access to enantiopure (S)-Profens and Profenols. Adv Synth Catal. 2018:360:2742-2751; doi:10.1002/adsc.201800541.

13. Kratzer R, Nidetzky B. Identification of Candida tenuis xylose reductase as highly selective biocatalyst for the synthesis of aromatic a-hydroxyesters and improvement of its efficiency by protein engineering. Chem Commun. 2007;10:1047-1049; doi:10.1039/B616475G.

14. Rapp C, Nidetzky B, Kratzer R. Pushing the limits: Cyclodextrin-based intensification of bioreductions. J Biotechnol. 2021; 325: 57-64; doi:10.1016/j.jbiotec.2020.11.017.

15. Couture J-F, Legrand P, Cantin L, Labrie F, Luu-The V, Breton R. Loop relaxation, a mechanism that explains the reduced specificity of rabbit 20alphahydroxysteroid dehydrogenase, a member of the aldo-keto reductase superfamily. J Mol Biol. 2004;339:89-102; doi:10.1016/j.jmb.2004.03.035.

16. Krump C, Vogl M, Brecker L, Nidetzky B, Kratzer R. Acceleration of an aldo-keto reductase by minimal loop engineering. PEDS. 2014;27:245-248; doi:10.1093/protein/gzu021.

17. Qiu S, Cheng F, Jin L-J, Chen Y, Li S-F, Wang Y-J, Zheng Y-G. Co-evolution of activity and thermostability of an aldo-keto reductase KmAKR for asymmetric synthesis of statin precursor dichiral diols. Bioorg Chem. 2020;103:104228; doi:10.1016/j.bioorg.2020.104228.

18. Kavanagh KL, Klimacek M, Nidetzky B, Wilson DK. The structure of apo and holo forms of xylose reductase, a dimeric aldo-keto reductase from Candida tenuis. Biochemistry. 2002;41:8785-8795; doi:10.1080/15216540600818143.

19. Kratzer R, Leitgeb S, Wilson DK, Nidetzky B. Probing the substrate binding site of Candida tenuis xylose reductase (AKR2B5) with site-directed mutagenesis. Biochem J. 2006;393:51-58; doi:10.1042/BJ20050831.

20. Leis D, Lauß B, Macher-Ambrosch R, Pfennig A, Nidetzky B, Kratzer R. Integration of bioreduction and product isolation: Highly hydrophobic cosolvents promote in situ substrate supply and extractive product isolation. J Biotechnol. 2017;257:110-117; doi:10.1016/j.jbiotec.2016.11.021.

21. Fuchs CS, Hollauf M, Meissner M, Simon RC, Besset T, Reek JNH, Riethorst W, Zepeck F, Kroutil W. Dynamic kinetic resolution of 2-phenylpropanal derivatives to yield $\beta$-chiral primary amines via bioamination. Adv Synth Catal. 2014;356:2257-2265; doi:10.1002/adsc.201400217.

22. Vogl M, Kratzer R, Nidetzky B, Brecker L. Candida tenuis xylose reductase catalysed reduction of acetophenones: the effect of ring-substituents on catalytic efficiency. Org Biomol Chem. 2011;9:5863-5870; doi:10.1039/C10B05510K.

23. Könst P, Merkens H, Kara S, Kochius S, Vogel A, Zuhse R, Holtmann D, Arends IWCE, Hollmann F. Enantioselective oxidation of aldehydes catalyzed by alcohol dehydrogenase. Angew Chemie Int Ed. 2012;51:9914-9917; doi:10.1002/anie.201203219.

24. Rocha-Martín J, Vega D, Bolivar JM, Hidalgo A, Berenguer J, Guisán JM, López-Gallego F. Characterization and further stabilization of a new antiprelog specific alcohol dehydrogenase from Thermus thermophilus HB27 for asymmetric reduction of carbonyl compounds. Bioresour Technol. 2012;103:343-350; doi:10.1016/j.biortech.2011.10.018.

25. LoPachin RM, Gavin T. Molecular mechanisms of aldehyde toxicity: a chemical perspective. Chem Res Toxicol. 2014; 27:1081-1091; doi:10.1021/tx5001046.

26. Kara S, Spickermann D, Schrittwieser JH, Leggewie C, van Berkel WJH, Arends IWCE, Hollmann F. More efficient redox biocatalysis by utilizing 1,4butandiol as a 'smart cosubstrate'. Green Chem. 2013;15:330-335; doi

27. Galletti P, Emer E, Gucciardo G, Quintavalla A, Pori M, Giacomini D. Chemoenzymatic synthesis of (2S)-2-arylpropanols through a dynamic kinetic resolution of 2-arylpropanals with alcohol dehydrogenases. Org Biomol Chem. 2010;8:4117-4123; doi:10.1039/C005098A.

28. Wuensch C, lechner H, Glueck SM, Zangger K, Hall M, Faber K. Asymmetric biocatalytic Cannizzaro-type reaction. ChemCatChem. 2013; 5:17441748; doi:10.1002/cctc.201300028.

29. Kelemen-Horváth I, Nemestóthy N, Bélafi-Bakó K, Gubicza L. Stereoselective reduction of 2-phenylpropionaldehyde by alcohol dehydrogenase with cofactor regeneration. Chem Papers. 2002;56:52-56.

30. Quaglia D, Pori M, Galletti P, Emer E, Paradisi F, Giacomini D. His-tagged horse liver alcohol dehydrogenase: Immobilization and application in the bio-based enantioselective synthesis of (S)-arylpropanols. Process Biochem. 2013;48:810-818; doi:10.1016/j.procbio.2013.03.016.

31. Sello G. Orsini F. Bernasconi S. Di Gennaro P. Selective enzymatic reduction of aldehydes. Molecules. 2006;11:365-369; doi:10.3390/11050365.

32. Chen S, Fujimoto Y, Girdaukas G, Sih CJ. Quantitative analyses of biochemical kinetic resolutions of enantiomers. J Am Chem Soc. 1982;104:72947299; doi:10.1021/ja00389a064.

33. Kavanagh KL, Klimacek M, Nidetzky B, Wilson DK. Structure of xylose reductase bound to NAD+ and the basis for single and dual co-substrate specificity in family 2 aldo-keto reductases. Biochem J. 2003; 373:319-326; doi:10.1042/bj20030286.

34. Kratzer R, Woodley JM, Nidetzky B. Rules for biocatalyst and reaction engineering to implement effective, NAD $(P) H$-dependent, whole cell bioreductions. Biotechnol Adv. 2015;33:1641-1652; doi:10.1016/j.biotechadv.2015.08.006. 
35. Satianegara G, Rogers PL, Rosche P. Comparative studies on enzyme preparations and role of cell components for $(R)$-phenylacetylcarbinol production in a two-phase biotransformation. Biotechnol Bioeng. 2006; 94:1189-1195; doi:0.1002/bit.20959.

36. Eixelsberger T, Woodley JM, Nidetzky B, Kratzer R. Scale-up and intensification of (S)-1-(2-chlorophenyl)ethanol bioproduction: economic evaluation of whole cell-catalyzed reduction of o-chloroacetophenone. Biotechnol Bioeng. 2013;110:2311-2315; doi:10.1002/bit.24896.

37. Lauß B, Rapp C, Leis D, Nidetzky B, Kratzer R. Separation behavior and microstructure of emulsified, two-phasic E. coli bioreaction mixtures. Colloids Interface Sci Commun. 2020;35:100248; doi:10.1016/j.colcom.2020.100248.

38. Trott O, Olson AJ. AutoDock Vina: Improving the speed and accuracy of docking with a new scoring function, efficient optimization and multithreading. J Comput Chem. 2009;31:455-461; doi: 10.1002/jcc.21334.

Figures

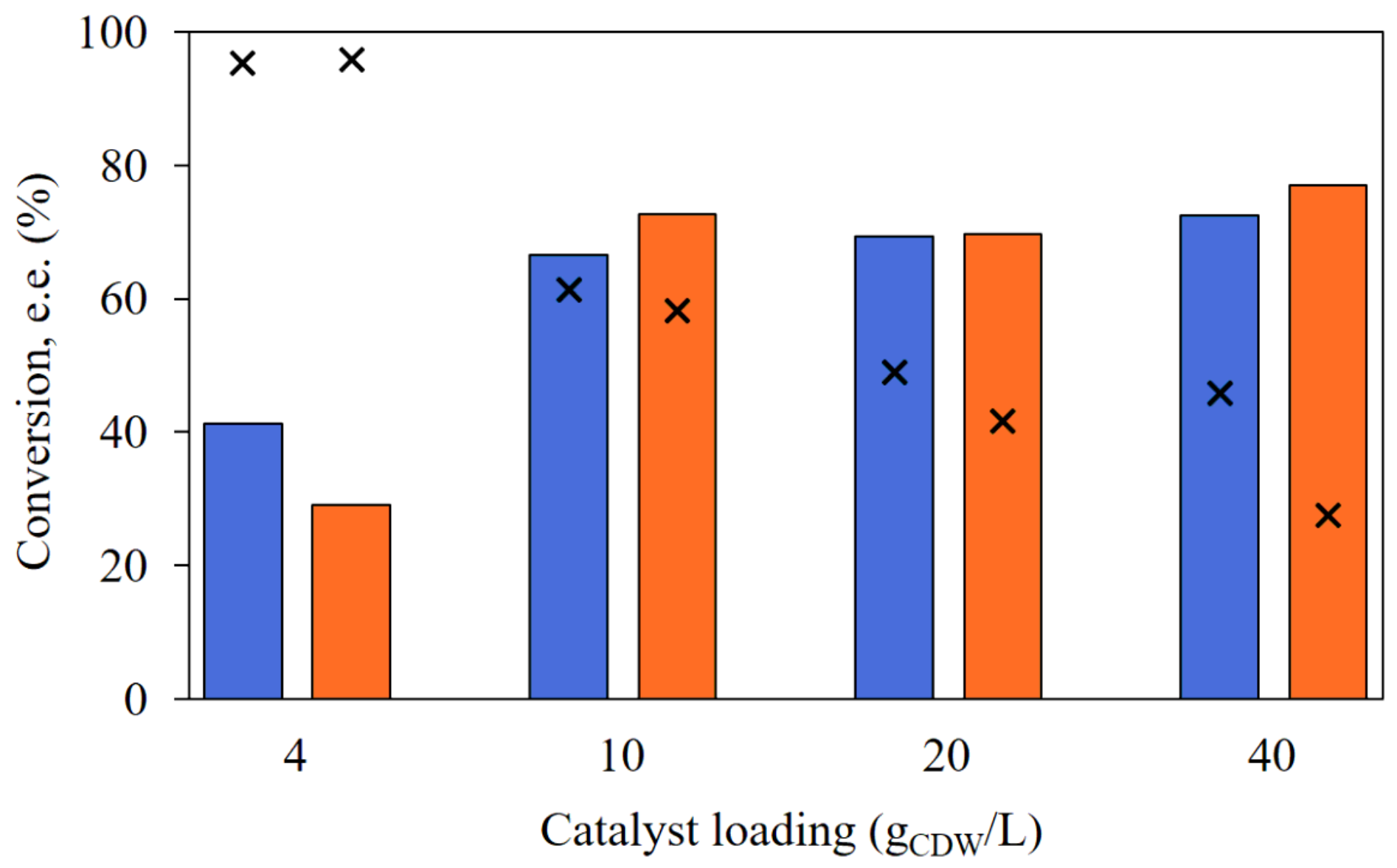

Figure 1

Conversions (\%, bars) and product e.e.-values (\%, crosses) of $100 \mathrm{mM}$ rac-2-phenylpropanal reduction by lyophilized whole-cell catalyst (blue bars) and cell-free catalyst (orange bars). Effects of catalyst form and loading were studied. NAD+ concentration 6 mM. Reaction time 24 h. Data are based on HPLC measurements, conversions are product concentrations. (For data see the Supplementary data.) 


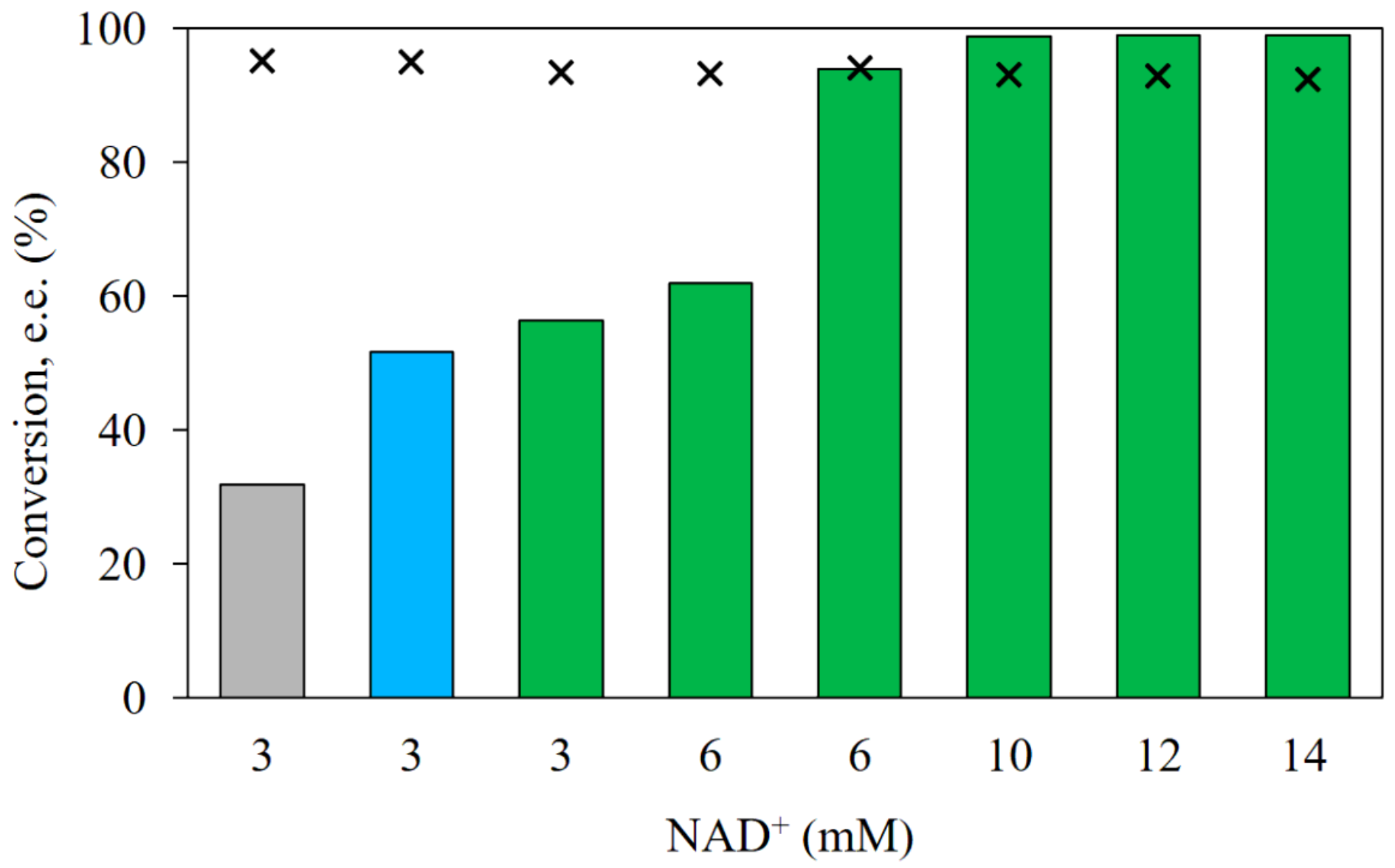

Figure 2

Conversions (bars) and product e.e.-values (crosses) of $1 \mathrm{M}$ rac-2-phenylpropanal reduction by lyophilized whole-cell catalyst (grey bars $20 \mathrm{gCDW} / \mathrm{L}$, blue bars $30 \mathrm{gCDW} / \mathrm{L}$, green bars $40 \mathrm{gCDW} / \mathrm{L}$ ). Effects of catalyst loading and co-enzyme concentration (NAD+3-14 mM) are shown. Reaction time $48 \mathrm{~h}$. Data are based on HPLC measurements, conversions are product concentrations. (For data see Table 3.) 


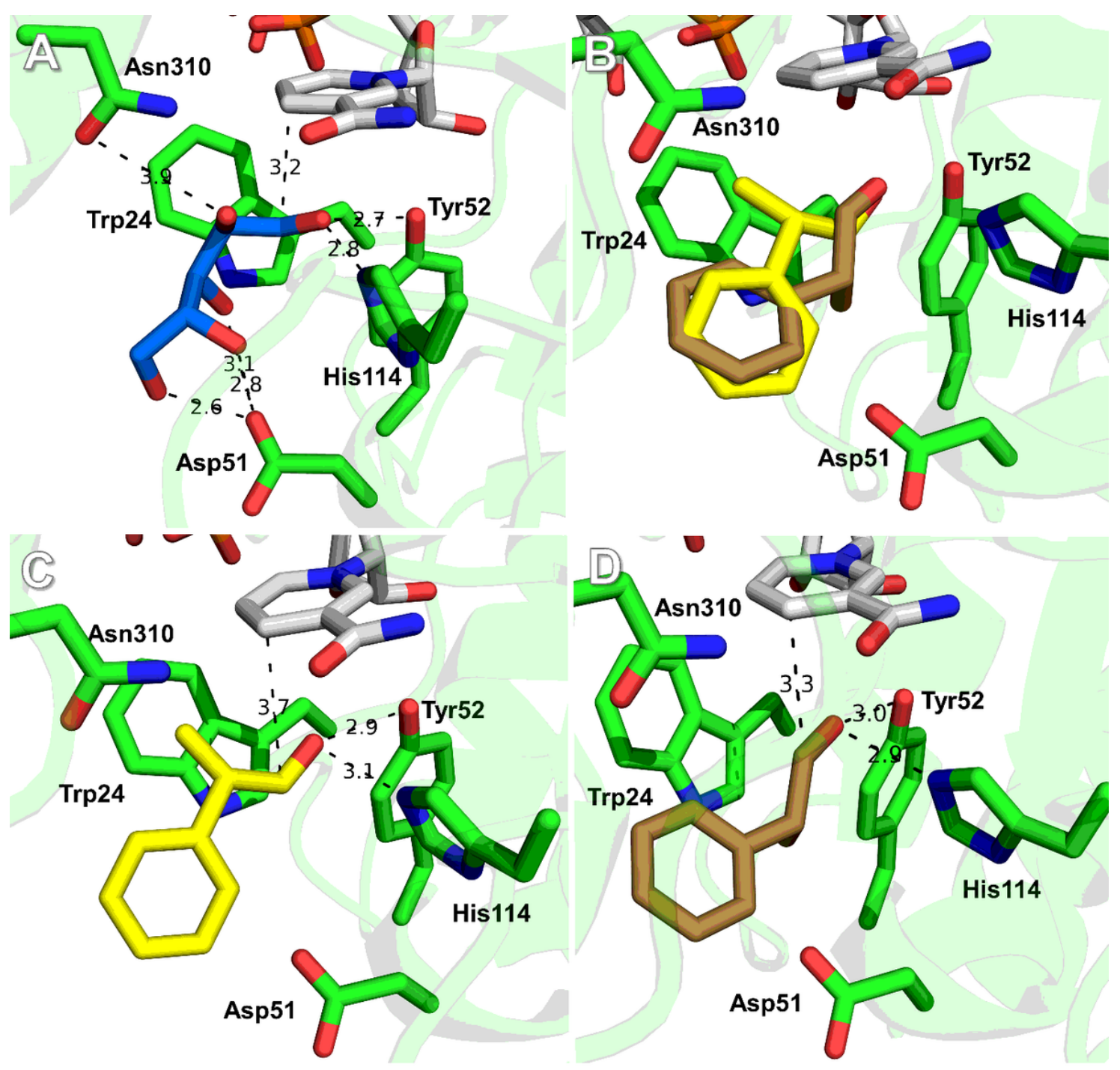

Figure 3

Wild-type CtXR active site with NAD+ (PDB 1MI3, 33) and modelled substrates. (A) Xylose (blue carbons, red oxygens), (B) (S)- and (R)-2-phenylpropanal (S-enantiomer yellow carbons, R-enantiomer brown carbons, red oxygens), (C) (S)-2-phenylpropanal (yellow carbons, red oxygen), (D) (R)-2-

phenylpropanal (brown carbons, red oxygen). Possible hydrogen bonds between substrates and the enzyme are shown as dashed lines, distances in $\AA$. 


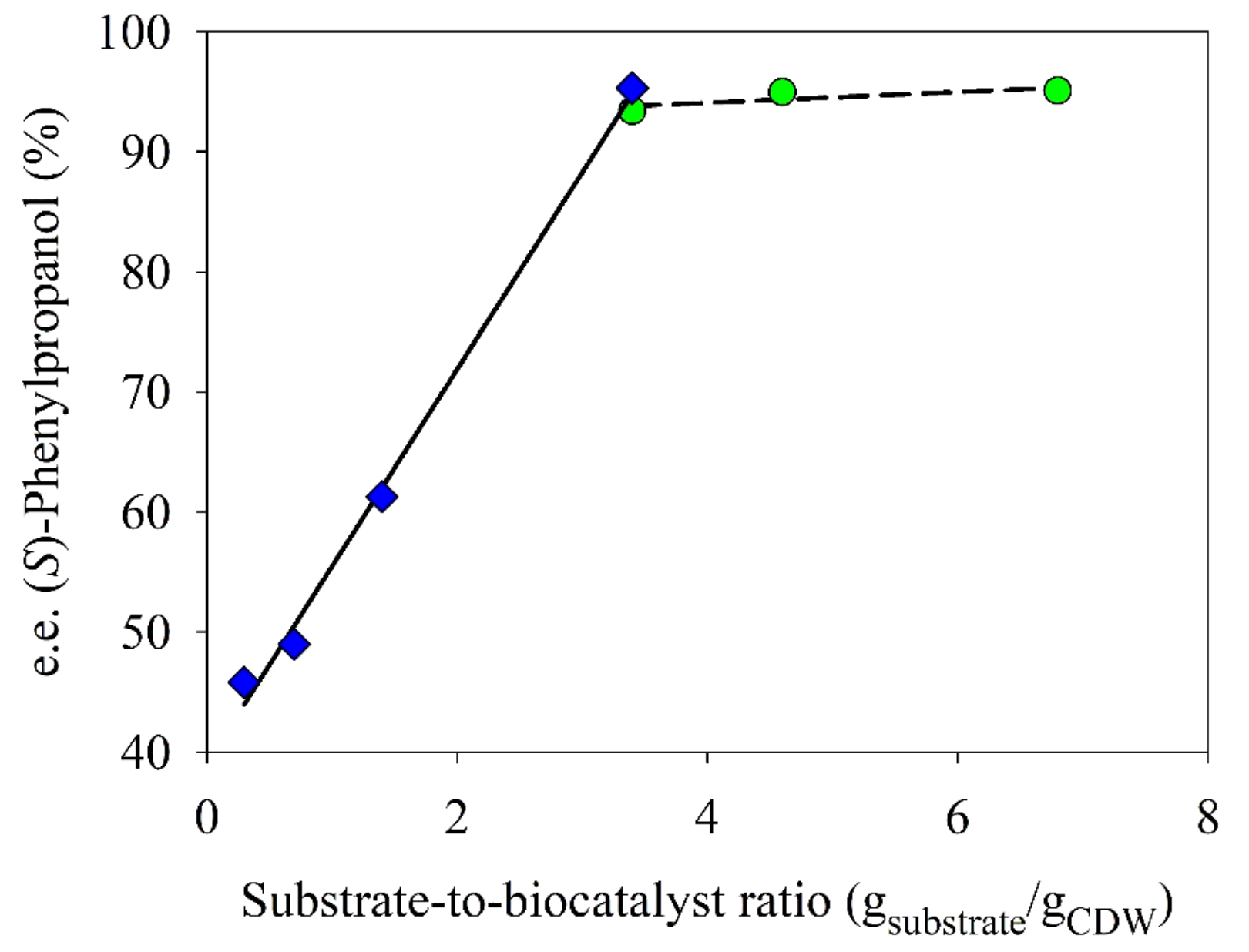

Figure 4

The effect of substrate-to-biocatalyst (whole-cell biocatalyst) ratio on product enantiopurity. Blue diamonds show conversions with $100 \mathrm{mM}$ rac-2phenylpropanal ( $3 \mathrm{mM} \mathrm{NAD+}$, reaction time $24 \mathrm{~h}$, data Figure 1), green circles conversions with $1 \mathrm{M}$ substrate (3 mM NAD+, reaction time $48 \mathrm{~h}$, data Figure 2), black cross conversion with $2 \mathrm{M}$ substrate (6 mM NAD+, reaction time $48 \mathrm{~h}$, data Table 3 ).

\section{Supplementary Files}

This is a list of supplementary files associated with this preprint. Click to download.

- scheme1.jpg

- Supplementarydataphprop1712.docx

- Graphicalabstract.jpg 